\title{
Will Molasses or Conditioning Increase Consumption of Spotted Knapweed by Sheep?
}

\author{
Travis R. Whitney ${ }^{1}$ and Bret E. Olson ${ }^{2}$ \\ Authors are ${ }^{1}$ Assistant Professor, Texas AひM University Research and Experiment Station, San Angelo, TX 76901; and ${ }^{2}$ Professor, Department of \\ Animal and Range Sciences, Montana State University, P.O. Box 172900, Bozeman, MT 59717.
}

\begin{abstract}
The spread of the invasive, Eurasian spotted knapweed (Centaurea maculosa Lam.) across the northwestern United States would be reduced if livestock regularly consumed it. We determined if white-face yearling ewes $(n=36)$ conditioned for 12 days to fresh-cut spotted knapweed, with or without molasses, would increase their use of it during a 5-day field trial and/or a 4-day drylot trial. Ewes were assigned to one of three treatments: ewes not conditioned to spotted knapweed or molasses (NC), ewes conditioned to spotted knapweed (SK), or ewes conditioned to spotted knapweed sprayed with liquid beet molasses (SKM). During conditioning, all groups consumed high amounts of their feed. Nonconditioned ewes (NC) consumed less than ewes conditioned to spotted knapweed (SK, SKM), indicating spotted knapweed did not inhibit initial consumption. In the field, SKM ewes spent more time grazing spotted knapweed and other forbs than SK ewes. In a drylot, time spent eating and intake of spotted knapweed and bromegrass (Bromus inermis Leyss.) varied through time. Conditioning yearling ewes to spotted knapweed, with or without molasses, did not increase consumption of this invasive plant, possibly because sheep inherently graze spotted knapweed only to a certain extent, or we did not use enough spotted knapweed during conditioning.
\end{abstract}

\section{Resumen}

La dispersión de la planta invasora "Eurasian spotted knapweed" (Centaurea maculosa Lam.) a lo largo del noroeste de Estados Unidos de América sería reducido si el ganado la consumiera regularmente. Determinamos si borregas cara blanca de un año $(n=36)$ acondicionadas por 12 días para consumir "Spotted knapweed" recién cortado con o sin melaza incrementaría su uso durante un experimento de campo de 5 días y/o en un experimento en corral de 4 días. Las borregas fueron asignadas a uno de tres tratamientos: 1) borregas sin acondicionamiento al "Spotted knapweed" o la melaza (NC), 2) borregas acondicionadas al "Spotted knapweed" (SK), y 3) borregas acondicionadas al "Spotted knapweed" asperjado con melaza líquida (SKM). Durante el acondicionamiento, todos los grupos consumieron altas cantidades de sus alimentos. Las borregas no acondicionadas (NC) consumieron menos que las acondicionadas al "Spotted knapweed" (SK, SKM), indicando que el "Spotted knapweed" no inhibe el consumo inicial. En el campo, las borregas SKM pasaron más tiempo apacentando "Spotted knapweed” y otras hierbas que las borregas SK. En el corral, el tiempo invertido en comer y el consumo de "Spotted knapweed" y "Bromegrass" (Bromus inermis Leyss.) varió a través del tiempo. El acondicionamiento de las borregas al "Spotted knapweed" con o sin melaza no incrementó el consumo de esta planta invasora, posiblemente porque los borregos en forma inherente apacientan el "Spotted knapweed," pero solo hasta cierta cantidad, o nosotros no utilizamos suficiente "Spotted knapweed" durante el acondicionamiento.

Key Words: Behaviour, grazing, intake

\section{INTRODUCTION}

The spread of invasive plant species, such as the Eurasian spotted knapweed (Centaurea maculosa Lam.), on rangelands of the northwestern United States could be reduced if its consumption by livestock could be enhanced. However, invasive plants are often unpalatable, or contain toxins that inhibit or reduce consumption.

To increase consumption of such plants, additives and supplements have been used to alter rumen metabolism, enhance detoxification, or provide positive postingestive

This research was funded by the USDA CSREES IFAFS, Award 2001-52103-11215.

At the time of this research, Whitney was a Post-doctoral Research Associate, Department of Animal and Range Sciences, Montana State University, P.O. Box 172900, Bozeman, MT 59717.

Correspondence: Bret E. Olson, Dept of Animal and Range Sciences, Montana State University, P.O. Box 172900, Bozeman, MT 59717. Email: bolson@montana.edu

Manuscript received 3 January 2006; manuscript accepted 17 May 2007. feedback for grazing animals (Bisson et al. 2001; Landau et al. 2002). Animals generally increase intake of a particular feed if they experience a positive response, or at least do not experience malaise (Provenza 1996). Further, animals that have had previous experience with a food consume more of that food than naïve animals (Green et al. 1984; Distel and Provenza 1991). Therefore, past experience influences future preference.

Molasses is used in animal production because it is palatable, and thus can increase dry matter and nitrogen intake (Bowman and Sowell 2003). Spraying senescent grass with molasses concentrates cattle to create and maintain firebreaks (Contra Costa Conservation District Office, personal communication, March 2004). Livestock producers have sprayed molasses on invasive plants, which increases consumption of those plants (G. Simonds, personal communication, September 1984).

Our objectives were to determine if 1) conditioning ewes to spotted knapweed enhances their subsequent consumption of 
the plant, 2) adding molasses enhances conditioning of ewes to spotted knapweed, and 3) ewes will consume spotted knapweed in a drylot four weeks after grazing noninfested spotted knapweed pastures.

\section{MATERIALS AND METHODS}

On 4 June 2004, 36 white-face yearling ewes (mean $\mathrm{BW}=55.1 \mathrm{~kg} \pm 5.3 \mathrm{SD}$ ) were randomly assigned to one of three treatments: ewes not conditioned to spotted knapweed or molasses (NC), ewes conditioned to spotted knapweed (SK), or ewes conditioned to spotted knapweed sprayed with liquid beet molasses (SKM). Experimental procedures were approved by the Institutional Animal Care and Use Committee at Montana State University.

\section{Conditioning: Days 0-11}

Ewes were individually penned at 0900 hours during conditioning. Non-conditioned ewes (NC) received $285 \mathrm{~g}$ of chopped $(2-5 \mathrm{~cm})$ oat hay $\cdot \mathrm{day}^{-1}$ (DM: dry matter basis). Ewes conditioned to spotted knapweed (SK) received $40 \mathrm{~g}$ of freshcut, chopped $(<7 \mathrm{~cm})$ spotted knapweed $(\mathrm{DM})$ combined with $245 \mathrm{~g}$ of chopped oat hay $\cdot \mathrm{day}^{-1}$. Ewes conditioned to spotted knapweed and molasses (SKM) received the same amounts of fresh-cut, chopped spotted knapweed and oat hay as SK ewes, but SKM ewes initially received $2 \mathrm{ml}$ of a dilute molasses spray (50:50 molasses:water) mixed with their feed to mimic what a livestock producer would spray on the plant in the field. For SKM ewes, molasses was increased from 2 to $4 \mathrm{ml} \cdot$ day $^{-1}$ over 3 days, and remained at $4 \mathrm{ml}$ for the remaining 9 days. Although mass of the fresh-cut spotted knapweed was only $16 \%$ of the chopped oat hay (DM), the volume of spotted knapweed offered greatly exceeded the volume of the oat hay.

Spotted knapweed plants were chopped and fed within 2 hours of harvest. Most of these plants were more than 2 years old, and had just started bolting. Sheep had 30 minutes to consume their feed. Feed tubs were then emptied, and feed refusals were weighed and recorded. Intake was not measured on day 1, so analyses include subsequent days only. Refusals primarily consisted of thick stems of spotted knapweed. When not in their pens, ewes were provided perennial grass hay (about 2.2\% body weight [BW], DM) with access to fresh water and mineral in a drylot.

\section{Field Trial: Days 12-17}

After conditioning, sheep were transported to an area infested with spotted knapweed. Each of three 0.3-ha pastures (blocks) was subdivided into three 0.1 -ha lanes. Four ewes from each conditioning treatment were assigned to a lane in each block. Spotted knapweed comprised $18 \%$ to $30 \%$ of the plant community. Beginning on the evening of June 16 (Period 1), ewes were observed during consecutive dusk (17002100 hours) and dawn (0500-0900 hours) grazing periods.

Three observers rotated among the three blocks, observing each ewe continuously for 180 seconds before moving onto the next ewe. Observers recorded time spent at different activities (grazing, ruminating, other). While recording "grazing," observers differentiated use of spotted knapweed, other forbs, annual grasses, and perennial grasses (Olson et al. 1996). After this trial, ewes were pastured for 28 days in an area dominated by perennial grasses without spotted knapweed.

\section{Drylot Trial: Days $\mathbf{4 6 - 4 9}$}

To determine if preferences would persist from the field trial, ewes were placed into one of three drylots on July 20. Each drylot was divided into three sections $\left(124 \mathrm{~m}^{2}\right.$ for each section) for each treatment. Ewes within treatments from the field trial were penned together. Each day at 1200 hours, $1 \mathrm{~kg}$ each of fresh-cut, chopped spotted knapweed and fresh-cut, chopped bromegrass (Bromus inermis Leyss.) per ewe (as-fed) were placed in four separate pairs of piles to minimize agonistic behavior in each section.

Three observers were randomly assigned to one of three treatments (NC, SK, SKM) within a block. They observed their assigned ewes for 30 minutes, and then reassigned treatments for 30 minutes observation periods in the remaining two blocks. They recorded each time any ewe in their assigned treatment altered their activity (feeding, traveling, ruminating). While feeding, observers noted whether each ewe was eating from a spotted knapweed or a bromegrass pile. After 30 minutes, unconsumed material was removed and weighed to determine intake. At the end of each day's trial, perennial grass hay was provided to each animal at approximately $2 \%$ BW (DM). Ewes had access to water and mineral.

\section{Forage Analysis}

During conditioning, samples of fresh-cut spotted knapweed, perennial grass hay, and chopped oat hay were collected. Samples were oven dried at $45^{\circ} \mathrm{C}$ for 48 hours, and stored until ground. Ash and crude protein $[\mathrm{CP}]$ were analyzed by standard methods (AOAC, 2000); CP was determined with a LECO Analyzer (Model FP-328, LECO Corp., Henderson, NV). Acid detergent fiber and neutral detergent fiber were analyzed according to Van Soest et al. (1991), although the procedure was modified for an Ankom 200 Fiber Analyzer (Ankom Technology Corp., Fairport, NY).

For the field trial, composition of spotted knapweed $(25.5 \% \pm 6.3 \mathrm{SE})$, bromegrass, $(51.7 \% \pm 10.1)$, cheatgrass (Bromus tectorum L.; $17.2 \% \pm 16.9$ ), and other forbs and perennial grasses was estimated visually. Based on 10 randomly-selected plots $\left(0.25 \mathrm{~m}^{2}\right)$, aboveground biomass averaged $1555 \mathrm{~kg} \cdot \mathrm{ha}^{-1} \pm 101 \mathrm{SE}$. On the last day, 10 samples of spotted knapweed and of other forages were collected adjacent to each block to determine nutritive value as described above. For the drylot trial, grass hay, and fresh-cut bromegrass and spotted knapweed were also sampled.

\section{Statistical Analyses}

Data were analyzed as a repeated-measures analysis of variance (PROC Mixed Procedure, Version 9.0; SAS Institute, Cary, NC) as a randomized complete-block design (Littell et al. 1998). The model included treatment (NC, SK, SKM), day, and their interaction. Block was the experimental unit, except during conditioning when ewes were randomly assigned to individual pens, whereby individual animals were experimental units. Observer and block were random errors during the field and drylot trials. Covariance structures (autoregressive order-1 


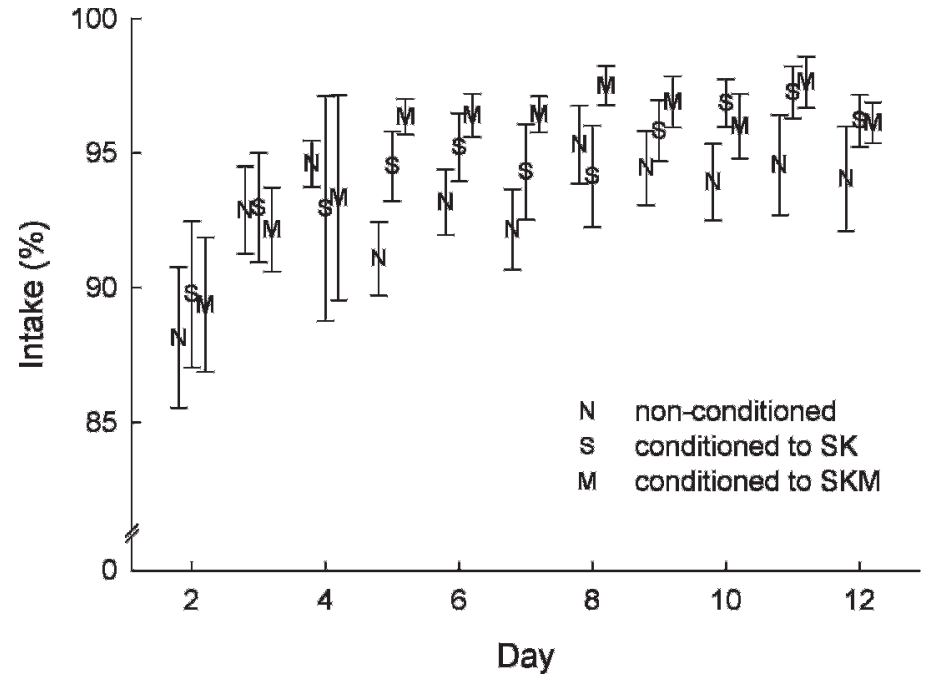

Figure 1. Forage intake (as-fed, $\% ; \pm 1$ SE) during the conditioning phase for yearling ewes in individual pens beginning 4 June 2004. $\mathrm{N}=$ ewes not conditioned to spotted knapweed (SK), $\mathrm{S}=$ ewes conditioned to only SK, $M=$ ewes conditioned to SK and molasses (SKM).

and compound symmetry) were compared to determine the most appropriate structure for each model. Compound symmetry was used for all variables.

Planned orthogonal contrasts included nonconditioned ewes vs. ewes conditioned with spotted knapweed, with or without molasses (NC vs. SK, SKM), and ewes conditioned with spotted knapweed vs. ewes conditioned with spotted knapweed and molasses (SK vs. SKM). $P$ values less than 0.10 are presented because of inherent variability among groups of animals and to let the reader assess biological importance (Gould and Steiner 2002).

\section{RESULTS}

Overall, spotted knapweed had greater crude protein and ash, and lower fiber (NDF, ADF) than the other forages (unpublished data).

\section{Conditioning Phase}

All groups consumed more of their assigned feeds as conditioning progressed (day, $P<0.001$ ), although this differed among treatments and moderated after day 5 (treatment by day interaction, $P=0.86$; Fig. 1$)$. SK and SKM ewes consumed more than NC ewes $(P=0.07)$.

\section{Field Trial}

The dominant annual grass was cheatgrass; the dominant perennial grass was bromegrass. Composition of spotted knapweed ranged from $18.3 \%$ to $30 \%$ among blocks.

SKM ewes spent more time grazing other forbs $(P=0.05)$, and, although not significant $(P=0.14)$, spotted knapweed than SK ewes in the field trial (Fig. 2A, B). Overall, time spent grazing spotted knapweed and other forbs varied by day (day, $P=0.07, P<0.0001$ ), respectively.

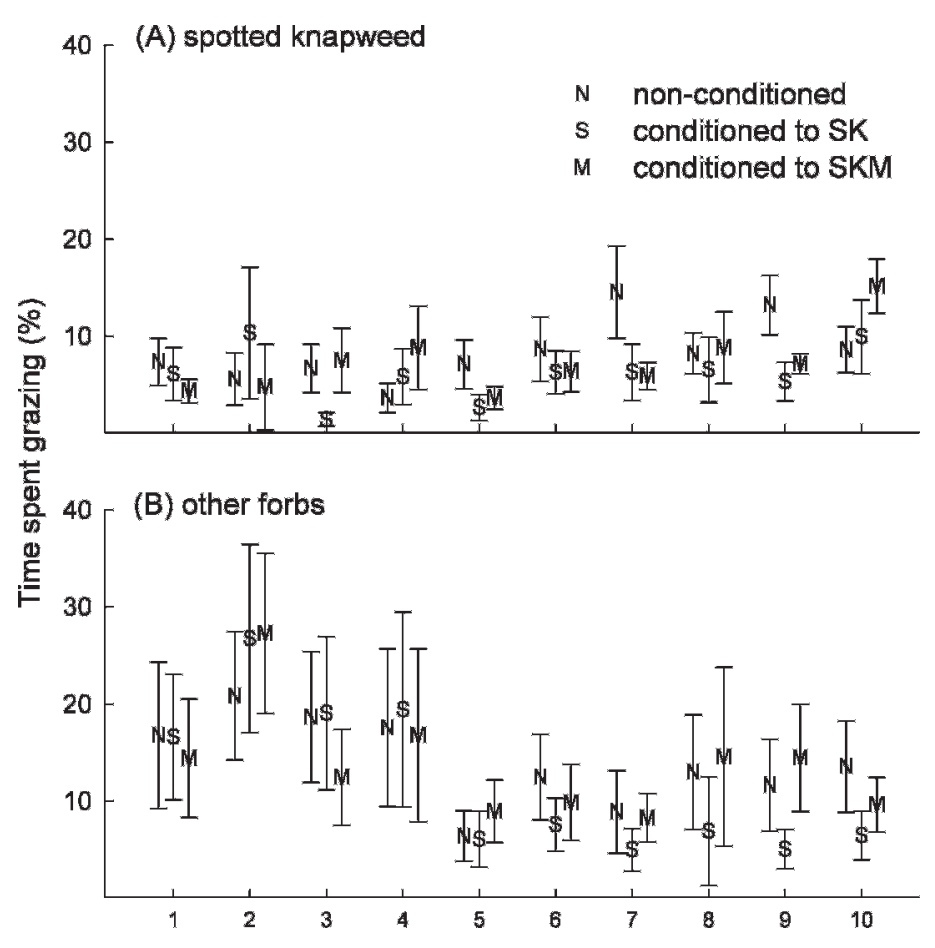

Figure 2. In the field, time spent grazing (\%, relative to total grazing time; $\pm 1 \mathrm{SE}$ ) spotted knapweed (A) or other forbs (B), for yearling ewes beginning 16 June 2004 (Period 1 = day 1 evening observation; Period 2 = day 2 morning observation; Period $3=$ day 2 evening observation, etc.). See Fig. 1 legend for treatment codes.

\section{Drylot Trial}

Time spent eating spotted knapweed and bromegrass varied by day during the Drylot Trial (day, $P=0.007$; Fig. $3 \mathrm{~A}$ ). Intake of spotted knapweed, especially bromegrass, varied by day (day, $P=0.09, P=0.0002$, respectively; Fig. 3B). SK ewes consumed more spotted knapweed than SKM ewes $(P=0.09)$.

\section{DISCUSSION}

\section{Conditioning}

We had hoped that ewes exposed to spotted knapweed would readily consume it in pens. All groups consumed most (>85\%) of their available feed. SK and SKM ewes actually consumed more than NC ewes indicating that spotted knapweed was not adversely affecting intake. Thus, our intent to expose the ewe to the plant without causing an aversive reaction was successful.

We sprayed molasses on spotted knapweed (SKM) to increase palatability. However, SK ewes, without molasses, consumed as much of the spotted knapweed-oat hay mix as SKM ewes. This could reflect that the amount of spotted knapweed did not exceed a threshold, aversive amount, or the amount of molasses was not enough to alter palatability. Apparently, the sweet taste and smell of molasses was not needed to overcome the bitter taste of spotted knapweed attributed to cnicin, a sesquiterpene lactone (Kelsey and Mihalovich 1987).

Most of the fresh-cut spotted knapweed plants fed during conditioning were greater than two years old, and had just started bolting. On another site in Montana, cnicin levels in 

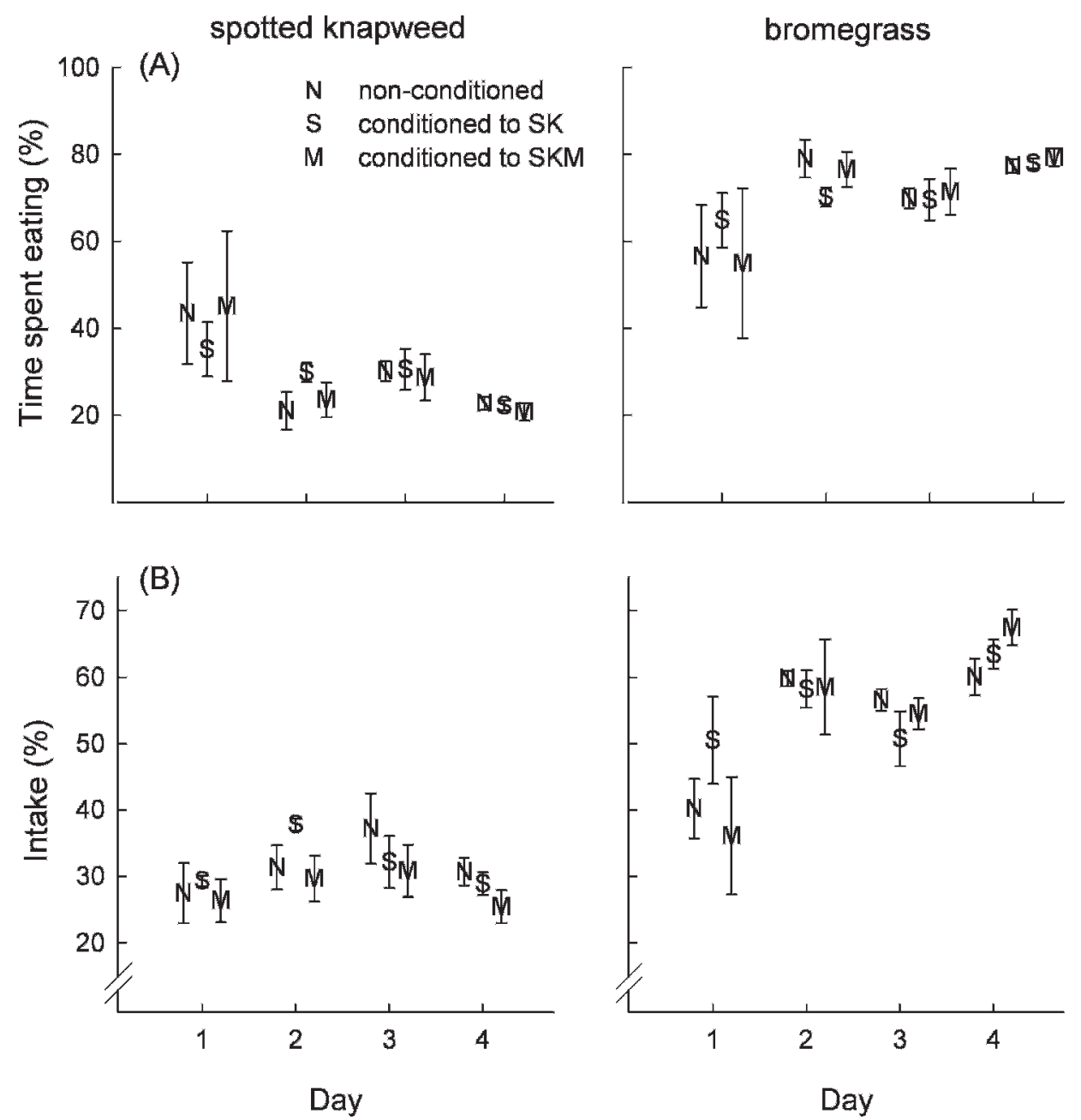

spotted knapweed + bromegrass

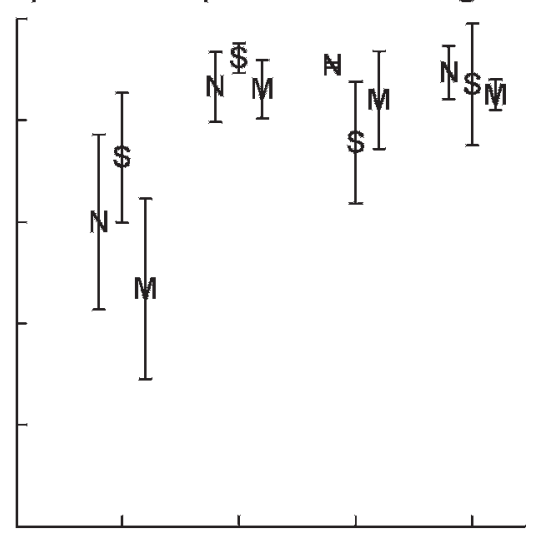

Figure 3. In the drylot, time spent $( \pm 1 \mathrm{SE})$ eating $(\mathbf{A})$ and intake $\mathbf{( B )}$ of fresh-cut spotted knapweed, fresh-cut bromegrass, or spotted knapweed and bromegrass for yearling ewes beginning 19 July 2004. See Fig. 1 legend for treatment codes.

young stems and leaves of spotted knapweed were $0.7 \%$ and $3.4 \%$ in mid-June, respectively (Olson and Kelsey 1997). High cnicin levels inhibit rumen microbial activity in vitro (Olson and Kelsey 1997), which could reduce intake of spotted knapweed via negative postingestive consequences. Consumption increased during conditioning, indicating cnicin was not causing malaise, and thus an aversion.

\section{Field Trial}

We thought conditioning ewes to spotted knapweed in pens would enhance consumption in the field. Preferences for forages are often affected by previous experience (Green et al. 1984; Olson et al. 1996). If anything, NC ewes spent more time grazing spotted knapweed than SK and SKM ewes, possibly because spotted knapweed was novel to them and young animals seek novelty.

Without conditioning, sheep will consume some spotted knapweed (Olson and Wallander 2001). Our intent was to enhance consumption via conditioning. Conditioned ewes readily consumed spotted knapweed during conditioning, but they were provided the spotted knapweed-oat hay mix only for a short period, and then fed grass hay. In the field, ewes had a wide variety of forages to select. In another study, sheep were conditioned to enhance their consumption of duncecap larkspur (Delphinium occidentale [S. Watts] S. Watts; Ralphs 2005). During a controlled preference test, conditioned ewes consumed more larkspur than ewes exposed as a group or unexposed ewes. In a subsequent field trial, conditioned ewes consumed more larkspur than control ewes, but only after most of the preferred forages had been consumed.

Time spent grazing spotted knapweed increased during the trial, but it seldom represented much of their time spent grazing $(<20 \%)$, which was similar to or less than its composition $(18 \%-30 \%)$ of the pasture. Thus, ewes did not prefer spotted knapweed even though it was considerably higher in crude protein and lower in fiber than the other forages. This might reflect its high cnicin content or the availability of more palatable forages.

Ewes varied in time spent grazing spotted knapweed from day 1 to day 5 in a rather cyclic pattern, e.g., SK ewes. Cyclic grazing benefits herbivores by allowing them to sample a variety of foods, reducing cumulative effects of toxins (Pfister et al. 1997). Herbivores consume less of a plant after a toxic "threshold" is reached that causes an aversion (Provenza 1996). If the aversion is not severe and/or if the forage is nutritious, the aversion diminishes rapidly (Ralphs and Cheney 
1993). Thus, animals can resample and continue consuming an aversive plant until the aversion reoccurs (Provenza 1996).

SKM ewes tended to spend slightly more time grazing spotted knapweed than SK ewes. Overall, the lack of a strong molasses effect could reflect that we did not use enough molasses during conditioning, or we did not reinforce its effect by applying it to spotted knapweed in the field. Our intent was to provide an early-season experience to spotted knapweed and molasses, and have that carryover into summer, which did not occur.

\section{Drylot Trial}

We thought conditioning ewes to spotted knapweed would enhance their consumption of it in the field, and that this enhancement would be present in a drylot one month later. Given that NC ewes consumed as much spotted knapweed as SK and SKM ewes in the field, the similarities in time spent eating and intake in the drylot was not surprising.

Overall, time spent grazing and intake of spotted knapweed in the drylot were lower than that of bromegrass. Ewes were presented with the same amount of fresh-cut spotted knapweed and bromegrass so this simple system was not confounded with varying amounts or alternative species, as in the field. They did not avoid spotted knapweed, but they definitely preferred bromegrass over spotted knapweed. Conversely, lambs conditioned to spotted knapweed, with or without their mothers, consumed more spotted knapweed in a drylot trial than lambs that were not conditioned (Whitney and Olson 2006).

In conclusion, conditioning white-face yearling ewes to the taste and texture of spotted knapweed, with or without molasses, did not noticeably enhance use of spotted knapweed in the field or drylot. This could reflect 1) their young age, i.e., their willingness to consume a certain amount with or without conditioning and an incentive (molasses); 2) the conditioning period was too short; or 3) we did not provide enough spotted knapweed or molasses during the conditioning phase to elicit a microbial or whole animal response.

\section{ACKNOWLEDGMENTS}

We thank Melany Cheeseman, Cedar Bossert, and Ilai Keren for observing ewes.

\section{LITERATURE CITED}

AOAC. 2000. Animal feed: general. In: N. J. Wendt Thiex [ed.]. Official methods of analysis. Volume 1, Chapter 4. 17th ed. Arlington, VA: Association Official Analytical Chemistry.

Bisson, M. G., C. B. Scott, and C. A. Taylor, JR. 2001. Activated charcoal and experience affect intake of juniper by goats. Journal of Range Management 54:274-278.

Bowman, J. G., AND B. F. Sowell. 2003. Delivery method and supplement consumption by grazing ruminants: a review. Journal of Animal Science 75:543-550.

Distel, R. A., And F. D. Provenza. 1991. Experience early in life affects voluntary intake of blackbrush by goats. Journal of Chemical Ecology 17:431-450.

Gould, W. R., and R. L. Steiner. 2002. Viewpoint: improving range science through the appropriate use of statistics. Journal of Range Management 55:526-529.

Green, G. C., R. L. Elwin, B. E. Mottershead, and J. J. Lynch. 1984. Long-term effects of early experience to supplementary feeding in sheep. Proceedings of the Australian Society for Animal Production 15:373-375.

Kelsey, R. G., and R. D. Mihalovich. 1987. Nutrient composition of spotted knapweed (Centaurea maculosa). Journal of Range Management 40:277-281.

Landau, S. Y., A. Perevolotsky, D. Kababy, N. Silanikove, R. Nitzan, H. Baram, and F. D. Provenza. 2002. Polyethylene glycol affects goats' feeding behavior in a tannin-rich environment. Journal of Range Management 55:598-603.

Littell, R. C., P. R. Henry, and C. B. Ammerman. 1998. Statistical analysis of repeated measures data using SAS procedures. Journal of Animal Science 76:1216-1231.

Olson, B. E., And R. G. Kelsey. 1997. Effect of Centaurea maculosa on sheep rumen microbial activity and mass in vitro. Journal of Chemical Ecology 23:1131-1144.

OLSON, B. E., AND R. T. Wallander. 2001. Sheep grazing spotted knapweed and Idaho fescue. Journal of Range Management 54:25-30.

Olson, B. E., R. T. Wallander, V. M. Thomas, and R. W. Kott. 1996. Effect of previous experience on sheep grazing leafy spurge. Applied Animal Behavioural Science 50:161-176.

Pfister, J. A., F. D. Provenza, G. D. Manners, D. R. Gardner, and M. H. Ralphs. 1997. Tall larkspur ingestion: can cattle regulate intake below toxic levels? Journal of Chemical Ecology 23:759-777.

ProvenzA, F. D. 1996. Acquired aversions as the basis for varied diets of ruminants foraging on rangelands. Journal of Animal Science 74:2010-2020.

RalPHS, M. H. 2005. Conditioning sheep to graze duncecap larkspur (Delphinium occidentale). Rangeland Ecology and Management 58:628-631.

Ralphs, M. H., and C. D. Cheney. 1993. Influence of cattle age, lithium chloride dose level, and food type in the retention of food aversions. Journal of Animal Science 71:373-379.

Van Soest, P. J., J. B. Robertson, and B. A. Lewis. 1991. Methods for dietary fiber, neutral detergent fiber, and nonstarch polysaccharides in relation to animal nutrition. Journal of Dairy Science 74:3583-3597.

Whitney, T. R., And B. E. OLson. 2006. Conditioning ewes and lambs to increase consumption of spotted knapweed. Applied Animal Behavioural Science 100:193-206. 